\title{
The Effects of Leaderships Styles, Work-Life Balance and Employee Engagement on Employee Performance
}

\author{
Putiri Bhuana Katili*, W. Wibowo, \& Maruf Akbar \\ Universitas Negeri Jakarta, Indonesia
}

\begin{abstract}
Employee Engagement is an important strategy on increasing company performance. The aims of this research is to elaborate influences of leadership styles and work- life balance to the employee engagement; also influence of employee engagement to the employee performance. To achieve this aim, the data was collected from 204 employees using questionnaire as instrument of research. The collected data was analyzed using SPSS and Structural Equation Modeling. This research conducted in steel industry. From this research can be concluded that work-life balance have most significant influence to employee engagement, and employee engagement have strong influence to the employee performance. By increasing leadership styles and work-life balance, the company could improve employee engagement. Therefore, the company management can utilize this research result for increasing employee performance and company competition.
\end{abstract}

Keywords: Employee engagement; leadership styles; work-life balance; employee performance.

\section{Introduction}

In recent years, employee management become important factor for employer growth. Especially, company that uses high technology operation have higher dependence on the employee performance and quality. Many companies started to focus on how to make employee more engaged and motivated for the employee best performances. Therefore, employee performance is strongly influenced by how engaged the employee to the company, usually called employee engagement.

Employee engagement is one of the topics that frequently discussed in recent research about employee performances. Employee engagement is considered to be factor to company's success in improving the employee performances. (Lockwood, 2007) explain that engagement affects employee performances. Engagement is an elusive force that motivates and individual to achieve higher levels of performance. Engaged employees will think that they have great influence on the company, and it will motivate them to go extra miles for the company.

Employee can be more motivated and engaged by various factor that occur during their work. The most common variables that affects employee engagement include, communication, learning and development, leadership, teamwork, job role, managing performance, people practice, customer focus, brand alignment and career opportunities (Hewitt, 2011) . Employees will be more motivated if they have good leader who can direct them clearly and guide them how to solve their problem. An ideal leader will make employees feel that they are an important part of the

\footnotetext{
* Corresponding author.

E-mail address: nori_satrio@yahoo.com (Putiri Bhuana Katili)
}

Quantitative Economics and Management Studies (QEMS) is licensed under an Attribution-NonCommercial-ShareAlike 4.0 International (CC BY-NC-SA 4.0) 
company. Another factor that can influence employee engagement is Work-life Balance. Work life balance can affect the employee engagement because employee must enjoy, healthy and happy if they want to achieve high productivity. Problem in their private life can affect their performance in work. The more flexible the company, employee can manage their private and work life easier.

This study discussed about employee engagement in company especially company that uses high technology operation. This study reviews recent findings as a basis in determining the factor affecting employee performance and determining the framework model. Factor affecting employee engagement and employee performance is discussed in this study. There are two factors discussed in this paper is leadership and work life balance. Furthermore, the framework model already made in this research and be tested to prove the model.

\section{Literature Review}

\subsection{Leadership Styles}

Leadership styles is the combination of attitude and behavior of a leader, which leads to certain action in dealing with the subordinates (Demirtas \& Akdogan, 2015). A good leader knows how to motivate the employee in achieving the goals of the organization, and that will help organization achieve their goals. Each leadership styles bring different consequences, which have direct and indirect impact on the employee's attitude and behavior (Yukl Gary, 2009). Good leader shows caring and appreciation to his employee. Good leader value his employee and the employee feel valued by their leader. If the employee feel valued for their contribution, it will affect their performance, less conflict, positive communication, and improved results in achieving organization's goal (Özer \& Tinaztepe, 2014)

\subsection{Work-life Balance}

Many research shows that good work-life balance pushes organization performance to a good direction, increase work satisfaction and improve organization commitment (Casper, Harris, Taylor-Bianco, \& Wayne, 2011). Work-life Balance is defined by balanced relationship in every aspect of attention, time, involvement and commitment. (Greenhaus \& Powell, 2006).

Specifically, Work-life balance is defined by balanced time allocation and psychology energy in and outside work (Clark, 2000). Characteristic of Work-life Balance is the presence of improved role and low of role conflict in and outside work.

(Alrowwad, Obeidat, Al-Khateeb, \& Masa'deh, 2018) stated that work-life balance is like balanced scale that one side is work life and the other side is personal life. As an addition, work-life balance can be interpreted as an idea that cover suitability between work, such as aspiration and career, and lifestyle, such as health, family, hobby, and others.

According to (Sharma \& Nayak, 2016) Work-life Balance is one of important variable from Turnover Intension. Work-life balance development indicates how organization believe that work life balance is important. Organization could improve policy of work-life balance for the employee so that they could balancing their work and personal life. Moreover, employee that have flexibility in their work time get less stressed, and conflict in their workplace. If the employee could manage and balanced their work in organization without getting stressed, they called to have a worklife balance.

(Connie, 2015) told that work-life balance strategy is individually important to managed health and welfare issue in workplace. Existing work-life balance policies and programs need to be evaluated because employee welfare and work-life balance affect to employee and organization performance. Work-life balance is stability of personal life and working life according to (Iqbal, Zia-ud-Din, Arif, Raza, \& Ishtiaq, 2017). Individual routine life usually consist of working life, and life outside of work, such as family life and friend life.

\subsection{Employee Engagement}

Based on (Karatepe, Yavas, Babakus, \& Deitz, 2018) and (Macey \& Schneider, 2008), employee engagement is how 
far the employee fully involved in their job in order to improve their commitment to their job and company. The employees that involved in the job and committed to work to reach excellent company competition by working highly productive, better service, and reducing the employee turnover.

Engagement is the energy that is needed by the employee get involved in their job to get better performance.(Rich \& Lepine, 2010). Moreover, engagement is employee positive behavior when they get support form the company and culture. Engagement is used in many terms in the researches such as personal engagement . Employee Engagement according to (Bakker, 2011), engagement is a process to create employee character in their role to solve their job. In employee engagement, employee use and express themselves physically, cognitively dan emotionally.

\subsection{Employee Performance}

Performance is importance to us as people and as organisations. Often performance is identified or equated with effectiveness and efficiency. As the performance of an organisation is dependent on the quality of the workforce at all levels of the organisations (Nickols, 2016). According to (Saeed et al., 2013), performance measurement is an ongoing activity for all managers and their subordinates, the measurement and its indicators are: quantity, quality, timeliness and cost-effectiveness. Employee Performance is the successful completion of task by a selected individual or individuals, as set and measured by a supervisor or organisation, to pre-defined acceptable standards while efficiently and effectively utilizing available resource within a changing environment.(Thao \& Hwang, 2010).

Based on (Kelidbari, Dizgah, \& Yusefi, 2015) defined employee performance as the important part in the organization so that the manager need to be focused to manage it. Moreover, (Bayraktaroğlu, 2013) state that performance is important factor for laying the foundation of organization. Performance must be critically analyzed so that employees get success. Same topic stated by (Muda, Rafiki, \& Harahap, 2014) that employee performance is whole performance in fulfilling expected quality based on policy and time. It is also stated by (Kelidbari, Dizgah, \& Yusefi, 2015) that performance could be used as comparison for promotion, redundancy, appreciation, sanction, judgement, and salary adjustment.

\section{Conceptual Model and Research Hypotheses}

Ciência \& Tecnologia dos Materiais accepts 1) Original Research Papers (Regular Papers); 2) Review Articles; and 3) Technical Notes.

This study is about independent variable of Leadership styles are derived from a study of (Alkhawaja, 2017), (Yuk1 Gary, 2009), in which there are 4 dimensions. Another independent variable is work-life balance is derived from (Bulger, Matthews, \& Hoffman, 2007), (Greenhaus \& Powell, 2006), in which there are 2 dimensions. Employee Engagement is evaluated based on model of (Lo \& Becker, 2011), (Saks, 2019), in which there are 3 dimensions. Employee Performance is evaluated based on (Daft Richard, 2010), (Dessler Gary, 2011), in which there are 4 dimensions. Relationship of 4 latent variable explained in Fig 1.

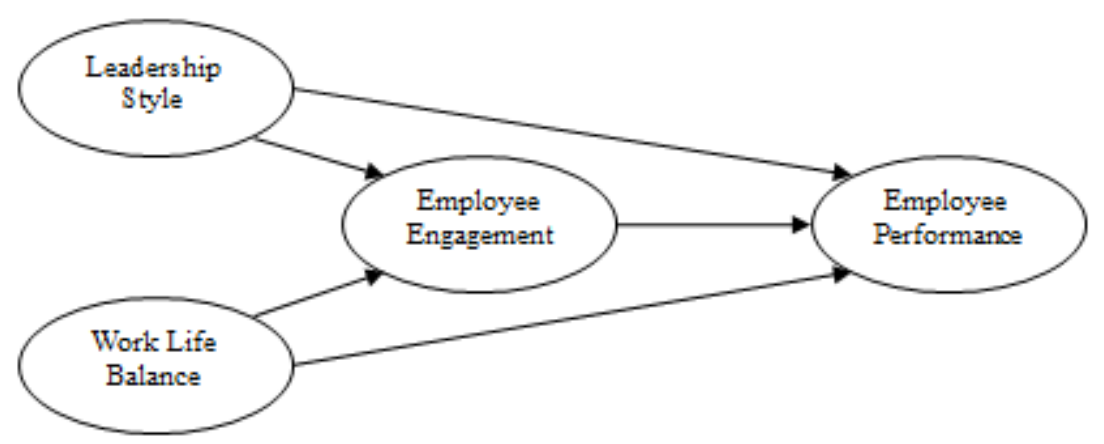

Fig. 1. Conceptual Model Research 


\subsection{Research Hypotheses}

- Leadership style effects on Employee Engagement.

- Work-life Balance effects on Employee Engagement.

- Leadership style effects on Employee Performance.

- Work-life Balance effects on Employee Performance.

- Employee Engagement effects on Employee Performance.

- Leadership style through Employee Engagement effects on Employee Performance.

- Work-life Balance through Employee Engagement effects on Employee Performance.

\section{Methodology}

The respondents of the research is included 204 employees who work in steel industry, which is located in Banten Province of Indonesia. The collected data was then analyzed using SPSS 20 and structural equation modelling (SEM) on Lisrel. SEM is used because previous literature regarded it as powerful statistical technique for generating more accurate and reliable findings (Kline, 2011), (Hair., Black, Babin, \& Anderson, 2014). Besides, SEM has recently emerged as a new generation tool to analyze the data and it has received a high attention from several scholars, particularly for studies that contain intervening variables. Data collection tool is closed questionnaires with Likert's five-option spectrum. 204 questionnaires were collected and 204 valid questionnaires were analyzed. Content validity was used to determine the validity, Cronbach's Alpha was used to determine the reliability, and these amounts for components more than 0.7 (Wijanto, 2015).

\section{Data Analysis}

\subsection{Describing the demographic data}

Table 1. Number and Percentage of Respondents Based on Demographic Variables

\begin{tabular}{llcc}
\hline Type of Classification & Category & Number & Percentage \\
\hline Gender & Male & 200 & $98 \%$ \\
& Female & 4 & $2 \%$ \\
\hline Age & Less than 30 years & 80 & $39.2 \%$ \\
& 30 to 40 years & 67 & $32.8 \%$ \\
& More than 40 & 57 & $28 \%$ \\
\hline Education & Diploma & 170 & $83.3 \%$ \\
& Graduate & 34 & $16.7 \%$ \\
\hline Work experience & Under 5 years & 76 & $37.3 \%$ \\
& 5 to 10 years & 52 & $25.5 \%$ \\
& 11 to 20 years & 43 & $21.1 \%$ \\
& More than 20 years & 33 & $16.1 \%$ \\
\hline Total & & 204 & $100 \%$ \\
\hline
\end{tabular}




\subsection{Testing the hypotheses}

Table 2. The results of the Structural Equation Modelling Implementation of Hypotheses

\begin{tabular}{lcccc}
\hline $\begin{array}{l}\text { Relation between variable of } \\
\text { research }\end{array}$ & t-Value & Direct Effect & Indirect Effect & Total Effect \\
\hline $\begin{array}{l}\text { Leadership Styles } \rightarrow \\
\text { Employee Engagement }\end{array}$ & 4.25 & 0.36 & - & 0.36 \\
\hline $\begin{array}{l}\text { Work-life Balance } \rightarrow \\
\text { Employee Engagement }\end{array}$ & 7.20 & 0.68 & 0.68 \\
\hline $\begin{array}{l}\text { Leadership Styles } \rightarrow \\
\text { Employee Performance }\end{array}$ & 0.18 & 0.06 & - & 0.06 \\
\hline $\begin{array}{l}\text { Work-life Balance } \rightarrow \\
\text { Employee Performance }\end{array}$ & 0.30 & 0.19 & - & 0.19 \\
\hline $\begin{array}{l}\text { Employee Engagement } \rightarrow \\
\text { Employee Performance }\end{array}$ & 0.44 & 0.50 & - & 0.44 \\
\hline $\begin{array}{l}\text { Leadership styles } \rightarrow \\
\text { Employee Engagement } \rightarrow \\
\text { Employee Performance }\end{array}$ & & - & 0.16 & 0.22 \\
\hline $\begin{array}{l}\text { Work-life Balance } \rightarrow \\
\text { Employee Engagement } \rightarrow \\
\text { Employee Performance }\end{array}$ & & - & 0.30 & 0.49 \\
\hline
\end{tabular}

\section{Discussion and Conclusion}

This result showed that leadership styles has a positive effect on employee engagement. The results also showed that leadership styles a positive effect on employee performance and the effect of leadership through employee engagement on employee performance is more than its direct effect on employee performance. So the employee engagement plays well the role of mediator. The research showed the same results on work-life balance effect as well as leadership styles effect through employee engagement on employee performance. So the employee engagement also plays well the role of mediator. The result of this research was in line with the results of research conducted by (Bedarkar \& Pandita, 2014), (Lockwood, 2007), (Hassan, 2016), (Popli \& Rizvi, 2016), (Amoako-asiedu \& Obuobisadarko, 2017), thus work-life balance have important role to the employee engagement. Balance between work life and personal life have big impact to the employee engagement, therefore employees give more effort in their job for improving organization performance. Leadership styles also have important role to the employee engagement. Leadership is the main tool of improving organization and leading them of effectiveness and efficiency. Leadership style is a combination of characteristics, skills and behavior that the managers uses them in order to interact with his employees. The leaders, who stimulate innovation through creating modern perspectives, motivate the followers and give them responsibility and commitment, will guarantee the organisation's survival and promote its growth.

\section{References}

Alkhawaja, A. (2017). Leadership Style and Employee Turnover A Mythical Relationship or Reality? University of San Diego.

Alrowwad, A., Obeidat, B., Al-Khateeb, A., \& Masa'deh, R. (2018). The Role of Work/Life Balance and Motivational Drivers of Employee Engagement on the Relationship between Talent Management and Organization Performance: A Developing Country Perspective. Modern Applied Science, 12(11), 35. http://doi.org/10.5539/mas.v12n11p35 
Amoako-asiedu, E., \& Obuobisa-darko, T. (2017). Leadership, Employee Engagement and Employee Performance in the Public Sector of Ghana. Journal of Business and Management Sciences, 5(2), 27-34. http://doi.org/10.12691/jbms-5-2-1

Bakker, A. B. (2011). An evidence-based model of work engagement. Current Directions in Psychological Science, 20(4), 265-269. http://doi.org/10.1177/0963721411414534

Bayraktaroğlu, S. (2013). Impact of Training and Development on Employees Performance in Bosnia and Herzegovina, 3(1), 2013.

Bedarkar, M., \& Pandita, D. (2014). A Study on the Drivers of Employee Engagement Impacting Employee Performance. Procedia - Social and Behavioral Sciences, 133, 106-115. http://doi.org/10.1016/j.sbspro.2014.04.174

Bulger, C. A., Matthews, R. A., \& Hoffman, M. E. (2007). Work and Personal Life Boundary Management: Boundary Strength, Work/Personal Life Balance, and the Segmentation-Integration Continuum. Journal of Occupational Health Psychology, 12(4), 365-375. http://doi.org/10.1037/1076-8998.12.4.365

Casper, W. J., Harris, C., Taylor-Bianco, A., \& Wayne, J. H. (2011). Work-family conflict, perceived supervisor support and organizational commitment among Brazilian professionals. Journal of Vocational Behavior, 79(3), 640-652. http://doi.org/10.1016/j.jvb.2011.04.011

Clark, S. . (2000). clark2000.pdf.

Connie, Z. (2015). Article Information, 37. Retrieved from https://www.emeraldinsight.com/doi/abs/10.1108/ER-102013-0142

Daft Richard. (2010). New Era of Management.

Demirtas, O., \& Akdogan, A. A. (2015). The Effect of Ethical Leadership Behavior on Ethical Climate, Turnover Intention, and Affective Commitment. Journal of Business Ethics, 130(1), 59-67. http://doi.org/10.1007/s10551-014-2196-6

Dessler Gary. (2011). Human Resource Management.

Greenhaus, J. H., \& Powell, G. N. (2006). When Work and Family Are Allies: A Theory of Work-Family Enrichment. The Academy of Man Marital statement Review, 31(1), 72-92. The Academy of Management Review, 31(1), 72-92. Retrieved from https://www.jstor.org/stable/pdf/20159186.pdf?casa_token=MsgCoIPsAPMAAAAA:SU8JT_9C68J6nNFxhW CwBQL0rCTCw88q11DAIWNpqnVdMWyfOZewOIUCUo-SeQf8CxHFH2vKcVH5YX1P_QeZW2MI47TmsKZPN_pU6XzN8XOabAXSLo

Hair., J. F., Black, W. C., Babin, B. J., \& Anderson, R. E. (2014). Multivariate Data Analysis William C . Black Seventh Edition.

Hassan, N. M. (2016). Work-life Balance: A Concern on Effectiveness of Job Role and Employee's Engagement towards Organizational Goal. International Journal of Academic Research in Business and Social Sciences, 6(11), 411-422. http://doi.org/10.6007/ijarbss/v6-i11/2410

Hewitt, A. (2011). The Multiplier Effect: Insights into How Senior Leaders Drive Employee Engagement Higher. Aon Hewitt, 1-8. Retrieved from http://www.aon.com/attachments/thought-leadership/Aon-Hewitt-Whitepaper_Engagement.pdf

Iqbal, I., Zia-ud-Din, M., Arif, A., Raza, M., \& Ishtiaq, Z. (2017). Impact of Employee Engagement on Work Life Balance with the Moderating Role of Employee Cynicism. International Journal of Academic Research in Business and Social Sciences, 7(6), 1088-1101. http://doi.org/10.6007/IJARBSS/v7-i6/3068

Karatepe, O. M., Yavas, U., Babakus, E., \& Deitz, G. D. (2018). The effects of organizational and personal resources on stress, engagement, and job outcomes. International Journal of Hospitality Management, 74(April), 147161. http://doi.org/10.1016/j.ijhm.2018.04.005 
Kelidbari, Dizgah, \& Yusefi, 2011). (2015). THE INTERNATIONAL JOURNAL OF BUSINESS \& MANAGEMENT The Impact of Employee Engagement in Improving Organizational Performance Abstract :, $3(2), 111-114$.

Kline, R. B. (2011). 〈Kline, R. B. (2011) Principles and Practice of SEM.pdf〉.

Lo, K. Y., \& Becker, D. E. (2011). Pore-pressure response beneath a ring foundation on clay. Canadian Geotechnical Journal, 16(3), 551-566. http://doi.org/10.1139/t79-060

Lockwood, N. R. (2007). Leveraging Employee Engagement for Competitive Advantage. Research Quarterly, 52(3), 1-12. http://doi.org/10.1109/HICSS.2007.324

Macey, W. H., \& Schneider, B. (2008). The Meaning of Employee Engagement. Industrial and Organizational Psychology, 1(1), 3-30. http://doi.org/10.1111/j.1754-9434.2007.0002.x

Muda, I., Rafiki, A., \& Harahap, M. R. (2014). Factors Influencing Employees 'Performance: A Study on the Islamic Banks in Islamic Science University of Malaysia University of North Sumatera. International Journal of Business and Social Sience, 5(2), 73-81.

Nickols, F. (2016). Factors Affecting Performance.

Özer, F., \& Tinaztepe, C. (2014). Effect of Strategic Leadership Styles on Firm Performance: A Study in a Turkish SME. Procedia - Social and Behavioral Sciences, 150, 778-784. http://doi.org/10.1016/j.sbspro.2014.09.059

Popli, S., \& Rizvi, I. A. (2016). Drivers of employee engagement: The role of leadership style. Global Business Review, 17(4), 965-979. http://doi.org/10.1177/0972150916645701

Rich, \& Lepine. (2010). Job Engagement: Antecedents and Effects on Job Performance Article in The Academy of. Academy of ManagementManagement Journal, 53(3), 617-635. http://doi.org/10.5465/AMJ.2010.51468988

Saeed, R., Mussawar, S., Lodhi, R. N., Iqbal, A., Nayab, H. H., \& Yaseen, S. (2013). Factors Affecting the Performance of Employees at Work Place in the Banking Sector of Pakistan. Middle-East Journal of Scientific Research, 17(9), 1200-1208. http://doi.org/10.5829/idosi.mejsr.2013.17.09.12256

Saks, A. M. (2019). Antecedents and consequences of employee engagement revisited. Journal of Organizational Effectiveness, 6(1), 19-38. http://doi.org/10.1108/JOEPP-06-2018-0034

Sharma, N., \& Nayak, P. (2016). Study on Work Life Balance and Organisation Policy in IT Sector in NCR. Amity Global Business Review, (November), 115-123.

Thao, T. L. T., \& Hwang, C. J. (2010). Factors Affecting Employee Performance - Evidence From Petrovietnam Engineering. Journal of Management Research, 21(3), 21-33.

Wijanto, S. H. (2015). Metode Penelitian menggunakan SEM dengan Lisrel 9.

Yukl Gary. (2009). Leadership in Organization. 